\title{
Antibiotics in wastewaters: a review with focus on Oman
}

\author{
Intisar Mohammed Al-Riyami ${ }^{1}$. Mushtaque Ahmed ${ }^{1} \cdot$ Ahmed Al-Busaidi $^{1}$ • B. S. Choudri ${ }^{2}$
}

Received: 7 September 2016 / Accepted: 5 October 2018 / Published online: 15 October 2018

(c) The Author(s) 2018

\begin{abstract}
The occurrence of antibiotics in treated wastewater effluent has been a concern worldwide for various reasons: most importantly development of antibiotics resistance by bacteria and other microorganism, impact of antibiotics on animal life in surface water and likely consequences on humans if treated wastewater is used for drinking water supply through the process of managed aquifer recharge (MAR). Another potential area of concern is the uptake of these antibiotics by crops irrigated by treated wastewater. In Oman, wastewater treatment and reuse is pursued vigorously as a government policy. Treated wastewater is used for crop irrigation following government regulations, MAR is being contemplated and practiced in small scale and release of such waters in the ocean takes place from time to time. Some tests have been conducted on the wastewater effluent around the world to verify and detect the concentration of antibiotics in wastewater effluent. In the Sultanate of Oman, very little research has been performed on the occurrence of antibiotics in treated wastewater, removal efficiencies of treatment processes and development of antibiotics resistance. It is expected that wastewater reuse will increase substantially due to expansion of sewerage network in the capital city as well as many other cities and towns. As such, it is imperative that research be undertaken to find out various issues related to commonly used antibiotics such as ciprofloxacin, norfloxacin, erythromycin, linezolid, penicillin, ampicillin, chloramphenicol, streptomycin, minocycline, tetracycline and sulfamethoxazole in Oman and their ultimate fate through the treatment process. In addition, the development of guidelines is crucial in amounts of antibiotics acceptably occurring in treated wastewater effluent and if they could be suitable for agriculture without causing any harm. A review of the available literature and data are provided in this article. Research needs have been identified.
\end{abstract}

Keywords Antibiotics $\cdot$ Occurrence $\cdot$ Wastewater $\cdot$ Treatment $\cdot$ Reuse $\cdot$ Oman

\section{Introduction}

Antibiotics are a type of pharmaceuticals used in the treatment of human and veterinary medicine. They inhibit the growth of different types of microorganisms for different diseases (Lindberg 2006). They were first discovered in the 1940s, starting with penicillin, which was coincidentally found to be produced by a fungus, later more antibiotics were developed from soil bacteria and now more antibiotics are synthesized antibiotics (Clardy et al. 2009).

Penicillin (a group of $\beta$-lactams) is the most common and oldest antimicrobial, which include naturally occurring

B. S. Choudri

bchoudri@squ.edu.om

1 College of Agricultural and Marine Sciences, Sultan Qaboos University, Muscat, Oman

2 Center for Environmental Studies and Research, Sultan Qaboos University, Muscat, Oman (penicillin G), aminopenicillins (ampicillin) and extendedspectrum (piperacillin). This penicillin group target to destruct the bacterial cell wall by destroying or inhibiting the production of peptidoglycan, which is one of the main components for cell wall synthesis (Hauser 2012). The presence of the antibiotic residues in the sewage treatment plants poses a problem due to the reasons such as increased risks to human health from the development of antibiotic-resistant microorganisms if antibiotics are present in sublethal concentrations of the pathogens in sewage (Al-Bahry et al. 2013).

In addition, the associated environmental health effects of antibiotics toward aquatic wildlife decrease in the sewage or wastewater treatment efficiency by changing in the concentrations of the active biomass involved in the secondary or tertiary sewage treatment due to exposure to antibiotics (Robinson et al. 2005; Kraigher et al. 2008). On the other hand, risks to human health and decreased treatment 
efficiency ultimately increase the cost of public and private health care for any given country in the world (Islam 2013).

Antibiotics work by inhibiting the growth of bacteria and its replication in different ways, which includes that of inhibiting the synthesis of the cell wall and the deoxyribonucleic acid. In the majority of the cases, antibiotics destroy the microorganisms, for example inhibiting the bacterial growth and allowing the recovery of the person or animal. There are different mechanisms of action for each class of antibiotic, which is also dependent on the target. The secondary treatment of wastewater is often based on the bacterial activity such as the activated sludge process; the existing facilities are often not designed completely to remove antibiotic residues from the sewage through the treatment process (Islam 2013).

Drug resistance could occur with fluoroquinolones by a mutation that changes the drug target (Blondeau 2004). Antibiotics such as macrolides (azithromycin and erythromycin) work on the ribosomes; they bind to 50S subunit of the ribosomes of the bacteria and inhibit its protein synthesis, leading to cell death, while trimethoprim and sulfamethoxazole inhibit important enzymes responsible for the biosynthesis of nucleic acid into dihydrofolate reductase and dihydrofolic acid (LexiCOMP 2016).

In this context, the current review is an attempt to provide an updated short review on the occurrence of antibiotics in the wastewater systems of Oman. The focus of review is on antibiotic consumption by human and their physicochemical properties and dynamics in the environment and systems of wastewater treatment related to Oman. Moreover, the knowledge gaps in the currently available information on antibiotics are identified and discussed along with this literature review.

\section{Methodology}

This paper is based on a literature review of texts and references sourced from policy documents, and published and unpublished reports. In order to reflect the overall status of antibiotics research in the environment focused on wastewater systems of Oman, a systematic literature review was performed using an electronic search of Web of Science (published in ISI), PubMed, Elsevier, Springer and Google Scholar. Literature published with focus on Oman was retrieved from the Ministries Web site. In addition, the literature review was also considered master's thesis and doctoral dissertation. It is imperative to mention that given the large number of studies that are available in the scientific literature, our review focused mostly on that scientific knowledge that was most related and important to the occurrence of antibiotics in wastewater environment. Therefore, secondary sources and reviews of published literature used in this article would form valuable indirect information on antibiotic focused in Oman.

\section{Pathway of pharmaceuticals in the environment}

Over the recent years, antibiotics are being considered as an emerging class of contaminants in the environment since they have been widely used in human and veterinary medicine and present in the environment through a complex cycle of transformation as well as bioaccumulation (Carvalho and Santos 2016). Antibiotics origin in the environment is divided into different sources such as humans, animals, agriculture, aquaculture and pharmaceutical manufacturers. It is mostly evident that humans are the most consumers of antibiotics and share great responsibility in antibiotics ending up in wastewater. Flushing down unused medications including antibiotics, in the toilets, could lead to accumulation of hefty amount of drugs in wastewater. In most houses around the world, there are bunch of medications that are stocked in cabinets and eventually get expired, which ends up to be flushed in the toilets (Harvard Health Letter 2011). Hospital effluent is also rich in antibiotics and in higher concentrations (Kummerer 2009). In addition, drug properties could affect the amount of drugs in wastewater. Drug metabolism could be one of the sources of drugs in wastewater. When a person or animal takes an antibiotic, the body metabolizes it to different chemicals, and only a small portion of it used by the body, while the rest excreted through urine and stool, which ultimately ends up in wastewater (Harvard Health Letter 2011). Another property that aids the accumulation of drugs in wastewater is their solubility. Most drugs are highly soluble in water and readily excreted, which makes it likely that ingested drugs will be transformed by the time they reach environment in varied quantity (Gulkowska et al. 2007) (Fig. 1).

Drug manufacturers could be another source of antibiotics in wastewaters, as waste products; many drugs could be precipitated (Gulkowska et al. 2007), but manufacturers should follow good manufacturing practice (GMP) regulations; thereby, no active drug would be emitted as a waste product and the amount could be insignificant (Kummerer 2009). On the other hand, the wastewaters generated specifically from the activities of agriculture, and aquaculture has not much of an input of antibiotics into the environment (Kummerer 2009).

\section{Wastewater treatment plants in Oman}

Oman and the Gulf countries have shortage in the abundance of water as the rainfall seasons are minimal in these countries. There are limited resources of freshwater, making it 


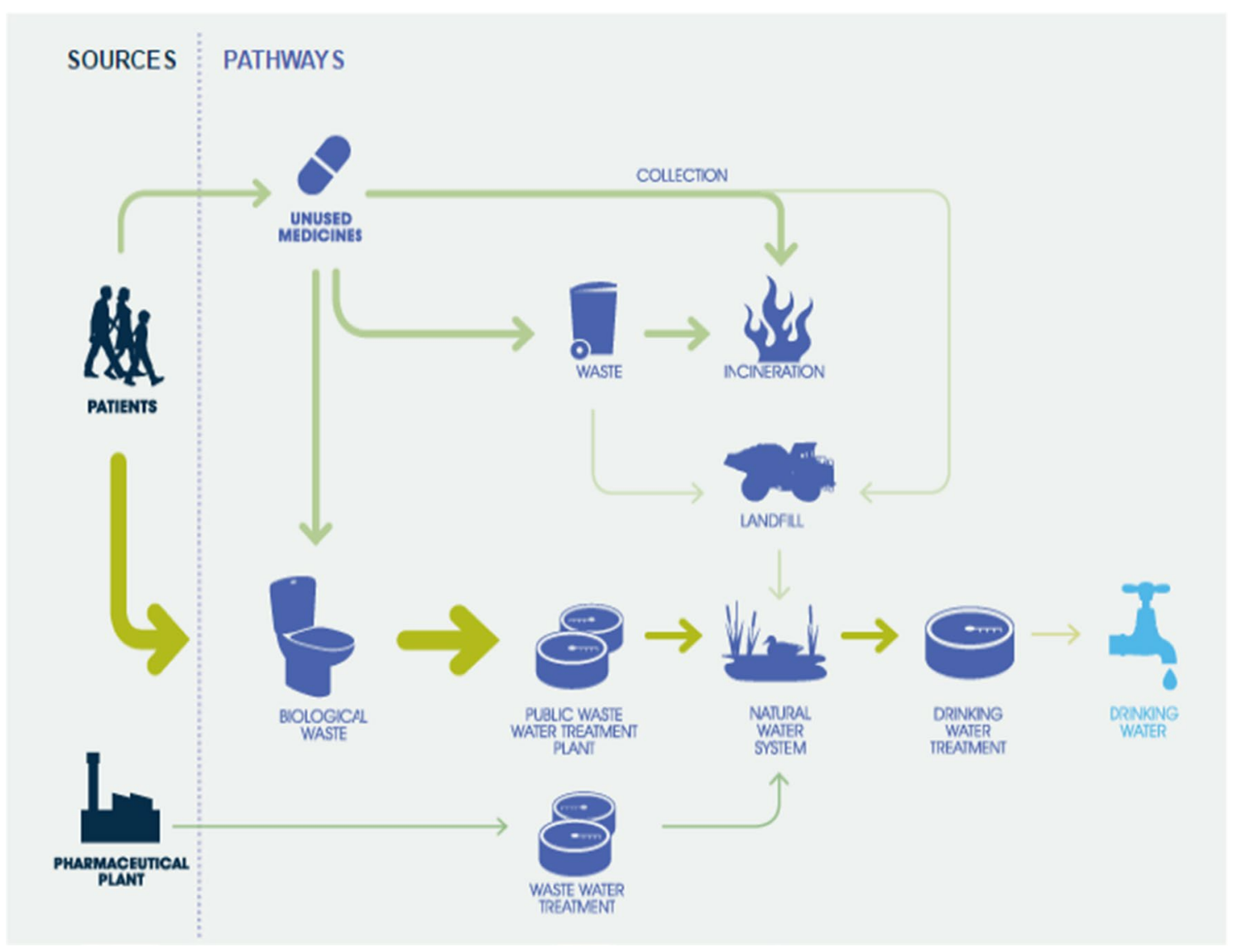

Fig. 1 Main sources and pathways of pharmaceutical residues in the environment (Sanofi 2016)

a huge challenge for agriculture in these countries to cover the least requirements and limiting its varieties. Therefore, it makes for Oman and other Gulf countries desperate to reuse wastewater through wastewater treatment plants and marks it extremely important as well as necessary to depend on them (Al-Jassim 2013; Abdul Khaliq et al. 2017a, b).

The aim of wastewater treatment plants is to reduce the solid particles available in the water, biodegradable organics, pathogenic bacteria and nutrients such as, phosphorus and nitrogen (Lindberg 2006; The World Bank Group 2016). Conventional wastewater treatment plants generally have different phases of treatment: primary, secondary and tertiary or advanced. Primary, also known as mechanical, removes solid particles from the sewage. Secondary, also known as biological, eliminates the organic matter that has bypassed the primary treatment, and the method is by using microorganisms that break down organic matter to carbon dioxide and water, in which those microorganisms salvage them to grow and reproduce. In addition, sludge process and tricking filters are few types of secondary treatment technologies. Tertiary treatment is the final step and is considered an additional phase, to remove the residual substances that are still found in the treated sewage by the primary and secondary treatments. The outcome effluent is considered "safe to be used" usually for agriculture use. Most wastewater treatment plants use chlorine as a disinfectant in the final step, but not all authorities agree on that (Lindberg 2006; The World Bank Group 2016; Waste Water Treatment Manuals 1997).

Although wastewater plants are not specifically planned to remove pharmaceuticals, these treatments can remove good amount of it, depending on the property of pharmaceuticals (chemical or physical) present in the particular wastewater. Most wastewater treatment plants have some type of biological treatment; this phase is involved in the removal of some amount of pharmaceuticals. Some other advanced methods including activated carbon, ozonation and advanced oxidation have shown to be better in the removal of pharmaceuticals than the biological treatment (WHO 2011).

In Oman, specifically at Al Ansab (Fig. 2), a wastewater treatment plant (operated by the Haya wastewater treatment company), the process is very similar to what is done around the world; they have primary, secondary and tertiary treatments for wastewater (Abdul Khaliq et al. 2017a). Figure 2 explains what is done at $\mathrm{Al} \mathrm{Ansab} \mathrm{wastewater} \mathrm{treatment}$ plant (Haya wastewater 2016). 


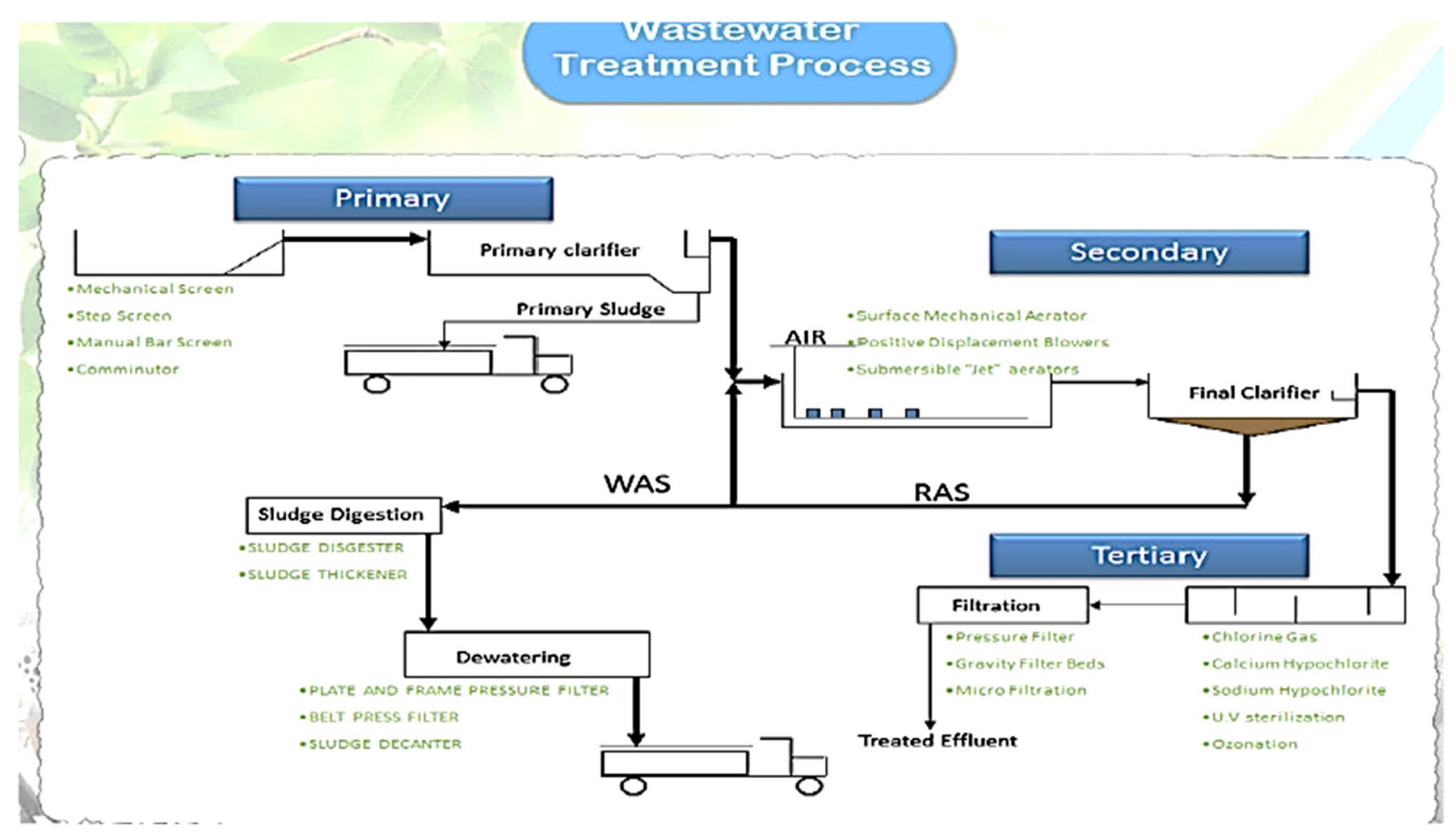

Fig. 2 Wastewater treatment process at Al Ansab, Muscat, Oman (Haya wastewater 2016)

\section{Tests used to analyze wastewater for antibiotics}

The occurrence of pharmaceuticals in general and antibiotics in specific in wastewater is very low in concentration as it becomes diluted (Mahmoud et al. 2013), making its analysis a challenge (Kasprzyk-Hordern et al. 2008). Therefore, a more accurate and an advanced measuring technology is needed (Kasprzyk-Hordern et al. 2008). Liquid chromatography with mass spectrometer was the most common analytical methods used to detect a wide range of environmental pollutants in water, including pharmaceuticals (Fatta et al. 2007; LEXI-COMP 2016a, b, c; Boeckel et al. 2015; Karthikeyan and Meyer 2006). In addition, a study developed a simple methodology with direct injection of the samples by HPLC with diode array detection (DAD); for a multi-residue analysis of five antibiotics of different classes (Teixeira et al. 2008), this method helps in fast screening for antibiotics.

\section{Use of antibiotics in the World and Oman}

\section{Humans}

There is evidence of rapid increase in antibiotics consumption between the years 2000 and 2010 around the world; the increase was seen to be $36 \%$. Most of the increase was in developing countries. India was the largest consumer of antibiotics with $12.9 \times 10^{9}$ units (10.7 units per person), followed by China with $10 \cdot 0 \times 10^{9}$ units ( $7 \cdot 5$ units per person), then the USA with $6.8 \times 10^{9}$ units ( 22.0 units per person) in 2010. Based on estimates reported most common antibiotics used globally, penicillin was used $\left(2.5 \times 10^{10}\right.$ standard unit $\log$ ), followed by cephalosporins (approx. $1.75 \times 10^{10}$ ), and followed by macrolides (approx. $0.85 \times 10^{10}$ ) and fluoroquinolones (approx. $0.75 \times 10^{10}$ ) (Boeckel et al. 2014).

The increase in antibiotics is definitely due to the improvement of healthcare services in the developing countries and growth of the population. But it could also be due to the overuse of antibiotics to self-limiting illnesses or used inappropriately. Unfortunately, among the enhanced consumption of antibiotics, is the increment of polymixin B throughout these years (Boeckel et al. 2014). Polymixin $\mathrm{B}$ is a bactericidal antibiotic, which causes leakage of the bacterial membrane leading to bacterial death (LEXI-COMP 2016a, b, c). Polymixin B is currently used as a last resort antibacterial and most commonly in antibiotic-resistant bacteria. The over use of polymixin B could mean that resistance has occurred and many antibiotics are not working (Boeckel et al. 2014).

In Oman, there are currently no published data on the amount of antibiotics used. At the Sultan Qaboos University Hospital (SQUH), the Pharmacy Department of Drugs 
information section has provided the most commonly used antibiotics in SQUH. Some of the reported antibiotics are: phenoxymethylpenicillin (penicillin), augmentin (penicillin), co-trimoxazole (combination of trimethoprim and sulfamethoxazole), cefuroxime (cephalosporin) and ciprofloxacin (fluoroquinolone). It is important to highlight that the list of consumed antibiotics in Oman shows a close association with the global trend in the use of antibiotics.

\section{Animals}

Antibiotics are also used in animals as well, up to double amount than humans for disease preventions and growth promotion. The demand on livestock worldwide has increased significantly over the years; therefore, producing countries have to maximize their production. One method is by giving antimicrobials to keep the animals in good health and maintain reproduction. There are studies that have shown that the use of antimicrobials on livestock is much higher than the human use. It is estimated that the annual use of antibiotics globally (antimicrobials per kilogram of animal produced) in cattle, chicken and pigs is $45 \mathrm{mg} / \mathrm{Kg}, 148 \mathrm{mg} /$ $\mathrm{Kg}$ and $172 \mathrm{mg} / \mathrm{Kg}$, respectively. According to Boeckel et al. (2015), an estimation of increment of antimicrobial use from the year 2010 to the year 2030 would be $67 \%$ (from $63,151 \pm 1560$ to $105,596 \pm 3605$ tons).

Unfortunately, the use of antimicrobials in animals is not regulated nor is it standardized in many countries, leading to overuse of antimicrobials, which eventually affects the environment (Boeckel et al. 2015). Just like the use of antibiotics in humans globally, the published data on antibiotics used in Oman are not available from the published sources.

\section{Common antibiotics found in wastewater effluent in different countries and Oman}

In different parts of Sweden, Lindberg (2006) did a study from the chemistry department of Umea University and reported that five different wastewater plants were studied for antibiotics in wastewater effluent. The study found that each plant had different antibiotics with different concentrations; the most common antibiotics were: fluoroquinolones, ofloxacin, ciprofloxacin, sulfamethoxazole, trimethoprim, and doxycycline. Further, it was reported that the usage and consumption of penicillins were the most consumed antibiotics in Sweden (Lindberg 2006).

Another study was conducted in Wisconsin, USA, and in this study seven wastewater treatment plant effluents were analyzed, the study found 6 different antibiotics in the effluent, different concentrations in different plants, and they were tetracycline $(0.07-0.37 \mu \mathrm{g} / \mathrm{L})$, trimethoprim (0.12-0.55 $\mu \mathrm{g} / \mathrm{L})$, sulfamethoxazole $(0.05-0.37 \mu \mathrm{g} / \mathrm{L})$, macrolides (approx. $0.3 \mu \mathrm{g} / \mathrm{L}$ ), and fluoroquinolones in the form of ciprofloxacin $(0.04-0.14 \mu \mathrm{g} / \mathrm{L})$. Not surprisingly, concentrations of those antibiotics were higher in the influents in comparison with the effluents. It was also noticed that there were change in concentrations with respect to different seasons (Karthikeyan and Meyer 2006).

Watkinson et al. (2009) explained the situation in Australia on the presence of antibiotics in five wastewater treatment plant effluents that were investigated in Queensland. The study was undertaken for effluents in order to find out a complete list of all antimicrobials. This study found that there were concentrations of macrolides, fluoroquinolones and sulfonamides ranging from 0.01 to $14.5 \mu \mathrm{g} / \mathrm{L}$. In comparison with the case of Sweden study, penicillin was the most consumed antibiotic in Australia, but minimum amount was found in the effluent. The overall extraction of antimicrobials comparing the influent with the effluent was about $80 \%$ by wastewater treatment plants.

A study in Hong Kong has demonstrated the existence of antibiotics in seven wastewater treatment plant effluents. The most common antibiotics found were fluoroquinolones (ofloxacin in the range of 96-7870 $\mathrm{ng} / \mathrm{L}$ ), norfloxacin (35-4000 ng/L), $\beta$-lactams (cefalexin in the range of $180-4000 \mathrm{ng} / \mathrm{L}$ ), macrolides (erythromycin in the range of 250-4000 ng/L), sulfamethoxazole (5-300 ng/L) and trimethoprim (60-450 ng/L). This study observed that wastewater treatment plants that use different phases of treatments such as primary, secondary and tertiary have the capacity to increase the removal efficiency (Leung et al. 2012).

It was shown from the above countries that the most common antibiotics found in wastewater plants effluent were fluoroquinolones, sulfonamides, macrolides and trimethoprim (Lindberg 2006; Karthikeyan and Meyer 2006; Watkinson et al. 2009; Leung et al. 2012). Several studies from different countries surprisingly showed high consumption of penicillin but low or minimal concentrations in effluents (Lindberg 2006; Watkinson et al. 2009; Leung et al. 2012). This factor can relate to the consumption of the most common antibiotics found in wastewater plant effluents. But what is surprising that penicillin was the most commonly used at the global scale, but none of the wastewater plants in the above countries reported its occurrence (Michael et al. 2013; Jelić et al. 2012).

There are no published data specifically on wastewater effluent testing for antibiotics in Oman, but there are studies on multiple drug resistance bacteria, which could indicate on the presence of antibiotics as well. Mahmoud et al. (2013) found that in treated wastewater effluent, there were multiple antibiotic-resistant bacteria and the most common antibiotics they were resistant are ampicillin $(83.3 \%)$ and carbenicillin (66.7\%), and none to sulfamethoxazole. This study indicates that inappropriate use of antibiotics in humans and animals has enhanced the development of 
antibiotic-resistant bacteria strains which could adversely affect the environment. Another study done in Oman by Al-Bahry et al. (2012) has demonstrated the most common multiple antibiotic-resistant bacteria resistance to antibiotics mainly ampicillin (100\%), sulfamethoxazole (approx. 95\%), carbenicillin (80\%), followed by streptomycin (approx. 77\%) and the rest of antibiotics.

\section{Reuse of wastewater effluent in Oman}

Reuse of wastewater effluent in Oman is mainly due to lack of freshwater resources, the large quantity of wastewater effluent availability, cost reduction and conservation of the freshwater available for other uses (Baawain et al. 2014a, b, 2015). In addition, due to the rapid development in agriculture and industrial sections in Oman over the past four decades, there is an increase in the demand of water (Mahmoud et al. 2013; Abdul Khaliq et al. 2017a). Oman's main water sources are: conventional and non-conventional. Conventional includes groundwater, aflaj and springs, while non-conventional includes desalinized water and treated wastewater (Al-Khamisi 2014).

Table 1 provides the information on wastewater treatment plants that are available in Oman, the treated effluent (TE) produced from each plant $\left(\mathrm{m}^{3} / \mathrm{d}\right)$ and their main applications (Baawain et al. 2014a). Although the main reuse of wastewater effluent in Oman is for landscape (Baawain et al. 2014b), agriculture is another application for treated effluent, due to the high demand of food and the development of agricultural areas; thus, freshwater or natural source of water is not enough. As per Al-Khamisi and Ahmed (2014), the amount of toxic or harmful pollutants tested on plants using treated effluent was found to be below the recommended safe limit standards.

A considerable amount of research has been performed in Oman on various issues related to wastewater. Wastewater

Table 1 Wastewater treatment plants in Oman. Source: Baawain et al. (2014a)

\begin{tabular}{llll}
\hline $\begin{array}{l}\text { Wastewater } \\
\text { treatment plants } \\
\text { (WWTPs) }\end{array}$ & TE $\left(\mathrm{m}^{3} / \mathrm{d}\right)$ & Sludge $(\mathrm{Ton} / \mathrm{d})$ & $\begin{array}{l}\text { Main TE appli- } \\
\text { cation }\end{array}$ \\
\hline Al-Ansab & 21,000 & 66 & Landscaping \\
Darsait & 18,000 & 33 & Landscaping \\
Rusayl Ind & 800 & $(\sim 2)$ & Landscaping \\
Rusayl Dom & 285 & $(\sim 0.7)$ & Landscaping \\
Salalah STP & 20,000 & 35.5 & Recharge Wells \\
Salalah Ponds & 1500 & $(\sim 3)$ & Wadi Overflow \\
Raysut Ind. & 150 & $(\sim 0.4)$ & Landscaping \\
Sohar STP & 6600 & $(\sim 15)$ & Landscaping \\
Sohar Ind. & 300 & $(\sim 0.8)$ & Landscaping \\
\hline
\end{tabular}

research focused on growing crops, impacts on soil, aquifer recharge using treated wastewater and other relevant issues (Al-Khamisi et al. 2016a, b; Al-Busaidi and Ahmed 2014; Abdel Rahman et al. 2011; Abdul Khaliq et al. 2017a; AlFarsi et al. 2018), whereas sludge produced as by-product of wastewater treatment was investigated for its quality and likely use in crop production and remediation of contaminated sites (Al-Busaidi et al. 2015; Padmavathiamma et al. 2014; Al-Busaidi 2014).

The World Health Organization (WHO) has set three different methodologies to establish guidelines for reuse of wastewater effluent in agriculture. First, "the absence of fecal indicator organisms in wastewater, there should be no indication of any fecal coliform in the treated wastewater effluent for it to be used for irrigation of crops"; Second, "the absence of a measurable excess of cases of enteric disease in the exposed population"; using epidemiological studies is to confirm no actual risk of infection of reusing treated wastewater effluent, and third "model-generated estimated risk below a defined acceptable risk"; estimation of an annual risk could be done by a quantitative microbial risk assessment (QMRA) model. Table 2 provides revised recommendations for reuse of treated wastewater in agriculture.

\section{The risk on humans and risk management}

The reuse of treated wastewater effluent for irrigation is a common practice in many countries; it is certain that the reuse of treated wastewater effluent contaminated with multiple antibiotic-resistant bacteria would also reach the watered crop; this could harm the end user of these vegetables or fruits (Al-Bahry et al. 2009; Al-Farsi et al. 2018). The use of treated wastewater effluent as a reuse in agriculture and crop growing has shown to reach the crops through root uptake. A study by Wu et al. (2012) has found that spinach and lettuce are the most vegetables that uptake pharmaceuticals and personal care products from reusing treated wastewater effluents used in the irrigation. From the pharmaceuticals detected, trimethoprim is the only antibiotic which had an uptake with detected concentrations of $1.1 \pm(0.2-0.4)(\mathrm{ng} / \mathrm{G}$ dry weight) in both lettuce and spinach, while sulfamethoxazole was detected but lower than the method detection limit. It is of a concern specifically in vegetables or fruits that are eaten raw or uncooked (Wu et al. 2012).

Livestock products that are polluted by antibiotics could result in harmful effects to the humans such as allergic reactions or anaphylaxis, and disturbing the microflora residing in the gastrointestinal tract. A proper withdrawal time should be kept before slaughtering the animal, to avoid having those pollutants in meat. This is also another mechanism in which resistance could occur (Kadim 2014). Kümmerer (2008) has studied antibiotics in wastewater extensively and has seen 
Table 2 Wastewater discharge and reuse standards A and B, Oman Source: MECA MD145/93

\begin{tabular}{|c|c|c|c|}
\hline$\#$ & Specification & (Class A) & (Class B) \\
\hline 1 & Crops & $\begin{array}{l}\text { Vegetables likely to be eaten raw. } \\
\text { Fruit likely to be eaten raw and within } 2 \text { weeks of any irrigation }\end{array}$ & $\begin{array}{l}\text { Vegetables to be cooked or } \\
\text { processed } \\
\text { Fruit if no irrigation within } \\
2 \text { weeks of cropping } \\
\text { Fodder, cereal and seed } \\
\text { crops }\end{array}$ \\
\hline 2 & Grass and ornamental areas & $\begin{array}{l}\text { Public parks, hotel lawns recreational areas. } \\
\text { Areas with public access } \\
\text { Lakes with public contact (except place which may be used for praying and hand } \\
\text { washing) }\end{array}$ & $\begin{array}{l}\text { Pastures } \\
\text { Areas with no public access }\end{array}$ \\
\hline 3 & Aquifer recharge & All controlled aquifer recharge & \\
\hline 4 & Method of irrigation & $\begin{array}{l}\text { Spray or any other method of aerial irrigation not permitted in areas with public } \\
\text { access unless with timing control }\end{array}$ & \\
\hline 5 & Any other reuse applications & Subject to the approval; of the Ministry & \\
\hline
\end{tabular}

that the amount of antibiotics eventually reaches the environment which is in the range of $\mathrm{ng} / \mathrm{L}$ to $\mu \mathrm{g} / \mathrm{L}$, which is thought to be negligible, but little is known about the fate of metabolites and how it affects humans. The low dose and long-term effect of medications or antibiotics in wastewater eventually reused in agriculture and reaching of human by consumption is also not known. The consequence on babies, fetuses and elderly should also be considered and studied (Kümmerer 2008). The occurrence of sub-therapeutic doses of antibiotics on bacteria over a prolonged period leads to resistance, which is a threat to the environment (Al-Bahry et al. 2009).

Little is known of the risks associated with effluents containing trace pollutants of antibiotics, although research in this area is developing. Oetken et al. (2005) demonstrated that the antiepileptic carbamazepine had a significant and specific chronic effect against the oligochaete chironomus at environmentally relevant concentrations. This is further highlighted by Flaherty and Dodson (2005) who observed chronic fluoxetine exposure at low concentration significantly increased the daphnia fecundity. Furthermore, a mixture of fluoxetine and clofibric acid caused significant mortality, and deformities and mixtures of three-to-five antibiotics elicited changes in daphnia sex ratio (Flaherty and Dodson 2005).

The research to date on human and animal exposures to pharmaceuticals and personal care products (PPCPs) has linked them to an array of carcinogenic, mutagenic and reproductive toxicity risks (Khan and Nicell 2015; Vasquez et al. 2015; Al-Farsi et al. 2017). A number of PPCPs act as endocrine disruptors, which interfere with the functions of hormonal systems in both humans and animals (Catanese et al. 2016; Kiyama and Wada-Kiyama 2015; Al-Farsi et al. 2017). Associations have been identified between endocrine disruptors and recent trends of increased incidences of breast and prostate cancers (Rochester 2013). Reproductive disorders have been found to occur following prenatal exposure to compounds such as diethylstilbestrol (Maeda et al. 2014; Wise et al. 2016; Al-Farsi et al. 2017).

A comprehensive review of the acute and chronic toxicities of PPCP compounds in aquatic organisms has been conducted (Brausch et al. 2012; Al-Farsi et al. 2017). Of the compounds investigated, dextropropoxyphene, sertraline, thioridazine and diphenhydramine were highlighted as having the greatest potential for acute toxicity to the studied algal, vertebrate and fish populations. Bacteria, fish and amphibians were found to be relatively insensitive to the acute toxicity of analgesic drugs, while phytoplankton and invertebrates were the most sensitive to the acute toxicity of these compounds.

Plant uptake of pharmaceuticals, which occurs when treated wastewater is reused for irrigation, may also affect plant development. It is, in part, unclear whether the negative effects on plants originate from direct damage to the plant by the pharmaceuticals themselves or whether the antimicrobial action of pharmaceuticals on soil microorganisms is responsible for the damage by affecting the plant-microorganism symbiosis. The latter is attributed to the fact that antibiotics in the soil may affect plant development indirectly by disrupting soil communities: The decrease in the number of soil bacteria leads to a lack of food for soil fauna (protozoa, nematodes, micro-arthropods) and finally affects soil function: Plant residues are decomposed more slowly, denitrification is slower, and therefore, nutrients are recycled more slowly. Degradation productions of these chemicals can also be considered as contaminants contributing to these complex mixtures that are present (Al-Farsi et al. 2017). There is even some evidence that these degradation products can be as active or toxic as their original compound (Halling-Sorensen et al. 2002; Sengeløv et al. 2003).

There is a poor understanding of the risks and effects that the pharmaceuticals and their metabolites implications. Some thoughts of the management to reduce risk are

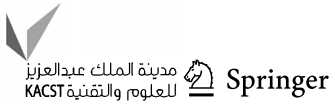


returning medications to pharmacies program, to avoid the flushing of unused medications. Another method is to have advanced effluent treatment plants, to minimize the amount of pharmaceuticals in the wastewater. In addition, prescribing awareness should be done such as the overuse of antibiotics in viral infections (Kümmerer 2008). Green and sustainable pharmacy could be one of the best options to solve the risk associated with pharmaceuticals. According to the principles of green chemistry (Anastas and Warner 1998), the functionality of a chemical should include the properties of a chemical necessary not only for its application, but also for its fast and easy degradability after its use. Taking into account the full life cycle of chemicals will lead to a different understanding of the functionality necessary for a chemical. In the present discussion, improvement of synthesis and renewable feedstock are very prominent, whereas the environmental properties of the molecules have been discussed less. Applying these principles and the knowledge of green chemistry to pharmaceuticals is necessary in the future.

\section{Research needs assessment}

The current state of antibiotics in wastewater research in Oman is giving its first steps. The main reason behind this is lack of laboratory facilities that are capable of measuring antibiotics at low concentrations. Trained manpower to carry out such laboratory measurements is also lacking. The first step in building a viable and sustainable research on this topic will require capacity building. Once such facilities and trained manpower are available, research should continue on finding out what antibiotics are present in wastewater at various stages of treatment, efficiency of various treatment systems (activated sludge, membrane bioreactor, constructed wetlands, adsorptions) to remove such pollutants and its persistence in treated wastewater, uptake by plants when irrigated with treated wastewater, accumulation in soils, movement to groundwater aquifers. Specific considerations should be given to prepare guidelines for the use of treated wastewater containing antibiotics for various purposes and develop appropriate standards based on research findings.

\section{Conclusion and recommendations}

Antibiotics have been found in treated wastewater effluent in different countries including Oman, and it was evident that more the treatment plant goes with subsequent stages of treatment, the less the amount of antibiotics occurred in the effluent. Resistance genes against various antibiotics have been isolated from the wastewater treatment systems and final effluents in the Sultanate of Oman. However, there are research and data gap on antibiotics in Oman; hence, more research is required, especially to study the effluents and its analysis for the concentration of antibiotics. In addition, this review also suggests investigating more advanced technologies, such as photo-catalysis and nanotechnology in wastewater treatment plants to get rid of antibiotics, which can eventually harm the environment, humans and animals. Further, development of guidelines is crucial in amounts of antibiotics acceptably occurring in treated wastewater effluent and if they could be suitable for agriculture without causing any harm.

Open Access This article is distributed under the terms of the Creative Commons Attribution 4.0 International License (http://creativeco mmons.org/licenses/by/4.0/), which permits unrestricted use, distribution, and reproduction in any medium, provided you give appropriate credit to the original author(s) and the source, provide a link to the Creative Commons license, and indicate if changes were made.

\section{References}

Abdel Rahman HA, Al-Khamisi SA, Ahmed M, Ali H (2011) Effects of treated wastewater irrigation on element concentrations in soil and maize plants. Commun Soil Sci Plant Anal 42:2046-2063

Abdul Khaliq SJ, Ahmed M, Al-Wardy M, Al-Busaidi A, Choudri BS (2017a) Wastewater and sludge management and research in Oman: an overview. J Air Waste Manag Assoc 67(3):267-278

Abdul Khaliq SJ, Al-Busaidi A, Ahmed M, Al-Wardy M, Agrama H, Choudri BS (2017b) The effect of municipal sewage sludge on the quality of soil and crops. Int J Recycl Org Waste Agric 6(4):289-299

Al-Bahry S, Mahmoud I, Al-Khaifi A, Elshafie A, Al-Harthy A (2009) Viability of multiple antibiotic resistant bacteria in distribution lines of treated sewage effluent used for irrigation. Water Sci Technol 60(11):236-245

Al-Bahry S, Mahmoud I, Al-Musharafi S (2012) Antibiotic resistant bacteria used as bioindicators of environmental pollution produced by tertiary treated sewage effluent. WIT Trans Ecol Environ 164:313-321

Al-Bahry SN, Al-Hinai JA, Mahmoud IY, Al-Musharafi SK (2013) Opportunistic and microbial pathogens in municipal water distribution systems. APCBEE Proc 5:339-343

Al-Busaidi A (2014) Usage of treated wastewater for bio-fuel production. In: Proceeding of the fifth joint GCC-Japan environment symposium, sustainable GCC environment: challenge for our future, March 3-5, Dahran, Saudi Arabia

Al-Busaidi A, Ahmed M (2014) Sustainable reuse of treated wastewater for agriculture. Int J Environ Water 3(5):66-73

Al-Busaidi A, Shaharoona B, Al-Yahiya R, Ahmed M (2015) Heavy metal concentrations in soils and date palms irrigated by groundwater and treated wastewater. Pak J Agric Sci 52(1):129-134

Al-Farsi R, Ahmed M, Al-Busaidi A, Choudri BS (2017) Translocation of pharmaceuticals and personal care products (PPCPs) into plant tissues: a review. Emerg Contam 3(4):132-137

Al-Farsi R, Ahmed M, Al-Busaidi A, Choudri BS (2018) Assessing the presence of pharmaceuticals in soil and plants irrigated with treated wastewater in Oman. Int J of Recycl Org Waste Agric $7(2): 165-172$

Al-Jassim NI (2013) Antibiotic resistant bacteria and their associated resistance genes in a conventional municipal wastewater treatment 
plant. Unpublished Master's Thesis, Sultan Qaboos University, Oman

Al-Khamisi SA (2014) Use of treated wastewater in crop production. In: Conference: symposium on disposal of large volumes of water: challenges and opportunities for arid environments in MAR practices. Sultan Qaboos University

Al-khamisi SA, Ahmed M (2014) Opportunities and challenges of using treated wastewater in agriculture. In: Shahid S, Ahmed M (eds) Environmental cost and face of agriculture in the Gulf Cooperation Council countries. Springer, Cham, pp 109-123

Al-Khamisi SA, Al-Wardy M, Ahmed M, Prathapar SA (2016a) Impact of reclaimed water irrigation on soil salinity, hydraulic conductivity, cation exchange capacity and micronutrients. J Agric Mar Sci 21(1):8-18

Al-Khamisi SA, Ahmed M, Al-Wardy M, Prathapar SA, Choudri BS (2016b) Effect of Reclaimed Water Irrigation on Yield Attributes and Chemical Composition of Wheat (Triticum Aestivum), Cowpea (Vigna Sinesis), and Maize (Zea Mays) in Rotation. J Irrig Sci 35(2):87-98

Anastas PT, Warner JC (1998) Green chemistry: theory and practice. Oxford University Press, New York, p 30

Baawain MS, Al-Omairi A, Choudri BS (2014a) Characterization of domestic wastewater treatment in Oman from three different regions and current implications of treated effluents. J Environ Monitor Assess 186(5):2701-2716

Baawain MS, Al-Jabri M, Choudri BS (2014b) Characterization of domestic wastewater sludge in Oman from three different regions and recommendations for alternative reuse applications. Iran J Pub Health 43(2): 168-177

Baawain MS, Al-Jabri A, Choudri BS (2015) Characterization of industrial wastewater sludge in Oman from three different regions and recommendations for alternate reuse applications. Iran J Pub Health 44(11):1473-1481

Blondeau JM (2004) Fluoroquinolones: mechanism of action, classification and development of resistance. Surv Ophthalmol 49(2):S73-S78

Boeckel T, Gandra S, Ashok A, Caudron Q, Grenfell B, Levin S, Laxminarayan R (2014) Global antibiotic consumption 2000 to 2010: an analysis of national pharmaceutical sales data. Lancet/ Infection. https://doi.org/10.1016/S1473-3099(14)70780-7

Boeckel T, Brower C, Gilbert M, Grenfell T, Levin S, Robinson T, Teillant A, Laxminarayan R (2015) Global trends in antimicrobial use in food animals. PNAS 112(18):5649-5654

Brausch JM, Connors KA, Brooks BW, Rand GM (2012) Human pharmaceuticals in the aquatic environment: a review of recent toxicological studies and considerations for toxicity testing. Rev Environ Contam Toxicol 218:1-99

Carvalho IT, Santos L (2016) Antibiotics in the aquatic environments: a review of the European scenario. Environ Int 94:736757. https://doi.org/10.1016/j.envint.2016.06.025

Catanese HN, Brayton KA, Gebremedhin AH (2016) Repeat analyzer: a tool for analyzing and managing short-sequence repeat data. BMC Genom 17:422

Clardy J, Fischbach M, Currie C (2009) The natural history of antibiotics. Curr Biol 19(11):R437-R441. https://doi.org/10.1016/j. cub.2009.04.001

Fatta D, Achilleos A, Nikolaou A, Meric S (2007) Analytical methods for tracing pharmaceutical residues in water and wastewater. Trends Anal Chem 26(6):126-135

Flaherty CM, Dodson SI (2005) Effects of pharmaceuticals on Daphnia survival, growth, and reproduction. Chemosphere 61(2):200-207

Gulkowska A, Yuhe H, So M, Yeung L, Leung H, Giesy J, Lam P, Martin M, Richardson B (2007) The occurrence of selected antibiotics in Hong Kong coastal waters. Marine Poll Bullet 54:1287-1306
Halling-Sorensen B, Sengelov G, Tjornelund J (2002) Toxicity of tetracyclines and tetracycline degradation products to environmentally relevant bacteria, including selected tetracycline-resistant bacteria. Arch Environ Contam Toxicol 42(3):263-271

Harvard Health Letter (2011) Drugs in the water. Harvard Health Publications, Harvard

Hauser AR (2012) Antibiotic basic for clinicians: The ABCs of choosing the right antibacterial agent, 2nd edn. Lippincott Williams \& Wilkin, Philadelphia (Chapter 5)

Haya wastewater Treatment Plant (2016). https://haya.om/tabid/135/ Default.aspx. Accessed 16 July 2016

Islam GMI (2013) Impact of tetracycline on microbial communities in the secondary treatment process of wastewater treatment systems. MSc thesis-Paper 1434, Ryerson University, Toronto, Canada

Jelić A, Gros M, Petrović M, Ginebreda A, Barceló D (2012) Occurrence and elimination of pharmaceuticals during conventional wastewater treatment. In: Guasch H, Ginebreda A, Geiszinger A (eds) Emerging and priority pollutants in rivers. The handbook of environmental chemistry, vol 19. Springer, Berlin

Kadim T (2014) Chemical contaminates of meat and meat products, which threaten human health. www.idosi.org/wjas/wjas2(3)/10. pdf. Accessed 10 Aug 2016

Karthikeyan K, Meyer M (2006) Occurrence of antibiotics in wastewater treatment facilities in Wisconsin, USA. Sci Total Environ 361:196-207

Kasprzyk-Hordern B, Dinsdale R, Guwy A (2008) Multi-residue methods for the analysis of pharmaceuticals, personal care products and illicit drugs in surface water and wastewater by solidphase extraction and ultra-performance liquid chromatographyelectrospray tandem mass spectrometry. Anal Bioanal Chem 391(4):1293-1308

Khan U, Nicell J (2015) Human health relevance of pharmaceutically active compounds in drinking water. AAPS J 17(3):558-585

Kiyama R, Wada-Kiyama Y (2015) Estrogenic endocrine disruptors: molecular mechanisms of action. Environ Int 83:11-40

Kraigher B, Kosjek T, Heath E, Kompare B, Mandic-Mulec I (2008) Influence of pharmaceutical residues on the structure of activated sludge bacterial communities in wastewater treatment bioreactors. Water Res 42(17):4578-4588

Kümmerer K (2008) Pharmaceuticals in the environment - a brief summary. In: Kümmerer K (ed) Pharmaceuticals in the environment. Springer, Berlin, pp 3-21

Kummerer K (2009) The presence of pharmaceuticals in the environment due to human use-present knowledge and future challenges. J Environ Manag 90:2354-2366

Leung HW, Minh TB, Murphy MB, Lam JC, So MK, Martin M, Lam PK, Richardson BJ (2012) Distribution, fate and risk assessment of antibiotics in sewage treatment plants in Hong Kong, South China. Environ Int 42:1-9

LEXI-COMP (2016a) Polymixin B Drug Monograph

LEXI-COMP (2016b) Drug monograph/Erythromycin Stearate. http:// www.uptodate.com/contents/erythromycin-systemic-drug-infor mation?source=search_result\&search $=$ erythromycin\&selectedTi tle $=1 \sim 145$. Accessed 30 June 2016

LEXI-COMP (2016c) Drug monograph/Co-Trimoxazole. http://www. uptodate.com/contents/trimethoprim-sulfamethoxazole-co-trimo xazole-drug-information?source=search_result\&search $=$ co-trimo xazole \&selectedTitle $=1 \sim 150$. Accessed 30 June 2016

LexiCOMP/Drugs monographs (2016) Macrolied and Co-Trimoxazole Lindberg R (2006) Environmental chemistry, department of chemistry, Umeå university, Umea, Sweden. Determination of antibiotics in the Swedish environment with emphasis on Sewage Treatment Plants

Maeda K, Poletto M, Chiapparino A, Gavin AC (2014) A generic protocol for the purification and characterization of water-soluble

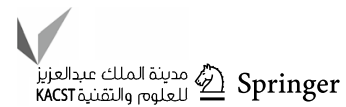


complexes of affinity-tagged proteins and lipids. Nat Protoc 9(9):2256-2266

Mahmoud I, Al-Bahry S, Al-Musharafi S (2013) Fresh water habitat pollution by treated sewage effluent in relation to multiple-antibiotic-resistant bacteria. APCBEE Procedia 5:363-367

Michael I, Rizzob L, McArdellc C, Manaiad C, Merline C, Schwartzf T, Dagotg C, Fatta-Kassinosa D (2013) Urban wastewater treatment plants as hotspots for the release of antibiotics in the environment: a review. Water Res 47:957-995

Oetken M, Nentwig G, Lçffler D, Ternes T, Oehlmann J (2005) Effects of Pharmaceuticals on Aquatic Invertebrates. Part I. The antiepileptic drug carbamazepine. Arch Environ Contam Toxicol 49:353-361

Padmavathiamma PK, Ahmed M, Abdelrahman H (2014) Phytoremediation-a sustainable approach for contaminant remediation in arid and semi-arid regions: a review. Emir J Food Agric 26(9):757-772

Robinson AA, Belden JB, Lydy MJ (2005) Toxicity of fluoroquinolone antibiotics to aquatic organisms. Environ Toxicol Chem 24(2):423-430

Rochester JR (2013) Bisphenol A and human health: a review of the literature. Reprod Toxicol 42:132-155

Sanofi (2016). http://en.sanofi.com/csr/planet/priorities/pharma_envir onment/pharma_environment.aspx. Accessed 15 June 2016

Sengel $\varnothing v$ G, Agers $\varnothing$ Y, Halling-Sørensen B, Baloda SB, Andersen JS, Jensen LB (2003) Bacterial antibiotic resistance levels in Danish farmland as a result of treatment with pig manure slurry. Environ Int 28(7):587-595

Teixeira S, Delerue-Matos C, Alves A, Santos L (2008) Fast screening procedure for antibiotics in wastewaters by direct HPLC-DAD analysis. J Sep Sci 31(16-17):2924-2931. https://doi.org/10.1002/ jssc. 200800229
The World Bank Group (2016) Introduction to wastewater treatment processes. The World Bank, Washington, USA. http://water.world bank.org/shw-resource-guide/infrastructure/menu-technical-optio ns/wastewater-treatment. Accessed 25 June 2016

Vasquez CG, Tworoger M, Martin AC (2015) Dynamic myosin phosphorylation regulates contractile pulses and tissue integrity during epithelial morphogenesis. J Cell Biol 206(3):435-450

Waste Water Treatment Manuals (1997) Primary, secondary and tertiary treatments. Environmental Protection Agency Ardcavan, Wexford, Ireland, 1/97/400

Watkinson A, Murbyd E, Kolpine D, Costanzof S (2009) The occurrence of antibiotics in an urban watershed: from wastewater to drinking water. Sci Total Environ 407:2711-2723

WHO (2011) Pharmaceuticals in drinking water. Public Health and Environment Water, Sanitation, Hygiene and Health. World Health Organization, WHO/HSE/WSH/11.05

Wise PM, Nattress L, Flammer LJ, Beauchamp GK (2016) Reduced dietary intake of simple sugars alters perceived sweet taste intensity but not perceived pleasantness. Am J Clin Nutr 103(1):50-60

Wu X, Conkle J, Gan J (2012) Multi-residue determination of pharmaceutical and personal care products in vegetables. J Chromatogr A $1254: 78-86$

Publisher's Note Springer Nature remains neutral with regard to jurisdictional claims in published maps and institutional affiliations. 